\title{
Effects of Blended (NPSB) Fertilizer Rates on Yield Components, Yield and Grain Quality of Bread Wheat (Triticum Aestivum L.) Varieties at Kulumsa, South-Eastern Ethiopia
}

\author{
Usman Kedir ${ }^{1 *}$, Tamado Tana ${ }^{2}$, Wogeyehu Worku ${ }^{3}$ \\ ${ }^{1}$ Adami Tulu Agricultural research center, Ziway, Ethiopia \\ ${ }^{2}$ Department of Plant Science, Haramaya University, Haramaya, Ethiopia \\ ${ }^{3}$ Kulumsa Agricultural Research Center, Asella, Ethiopia
}

*Corresponding Author: Usman Kedir, Adami Tulu Agricultural research center, Ziway, Ethiopia

\begin{abstract}
Bread wheat being one of the major food crops of the study area cultivated for both home consumption and market purposes. However, its productivity and grain quality is mainly constrained by lack of site specific fertilizer (NPSB) recommendation in the study area. Therefore, a field experiment was conducted at Kulumsa Agricultural Research Center during the 2017 main cropping season to evaluate the effect of blended NPSB fertilizer rates on yield components, yield and grain protein content; and to determine economically feasible rates of blended NPSB fertilizers for bread wheat production. Factorial combination of three improved bread wheat varieties (Hidase, Huluka and Kingbird) and four rates of NPSB fertilizers [0, 100, 150, 200 and NP (73/30)] were laid out in randomized complete block design with three replications. Analysis of the results revealed that lodging percentage (LP), number of kernels per spike (NKS), thousand kernels weight $(T K W)$, grain yield $(G Y)$, hectoliter weight $(H L W)$, and grain protein content $(G P C)$ were significantly affected by the main effect of fertilizers; similarly days to $50 \%$ maturity (DTH), lodging percentage (LP), number of kernels per spike (NKS), thousand kernels weight (TKW), aboveground dry biomass (AGB), straw yield (SY), harvest index (HI) and grain protein content $(G P C)$ were significantly affected by the main effect of varieties. while lodging percentage (LP), number of kernels per spike (NKS), thousand kernels weight (TKW)and grain protein content (GPC) were affected by both main effects of fertilizer and varieties. The highest NKS (48.3), TKW (43.8 g), HLW (82.9 $\left.\mathrm{kg} \mathrm{hL}^{-1}\right)$, were recorded from 150 $\mathrm{kg} \mathrm{NPSB}$, whereas GY (5935 $\left.\mathrm{kg} \mathrm{ha}^{-1}\right)$ and GPC (16.2\%) were recorded from 73/30 $\mathrm{kg} \mathrm{NP}$ and from no fertilizer application, respectively. Among the varieties, Hidase (57.93 days) and Kingbird (61.53 days) reached days to 50\% heading earlier than Huluka (62.73 days). Variety kingbird score the maximum number of kernels per spike (47.1) and gave the highest harvest index (48.5\%) whereas, variety Huluka gave the highest above ground biomass (14080 $\mathrm{kg} \mathrm{ha}^{-1}$ ) and straw yield (8242 $\left.\mathrm{kg} \mathrm{ha}^{-1}\right)$. In general, the economic feasibility of the fertilizer over varieties combination indicated that application of $100 \mathrm{~kg} \mathrm{NPSB} \mathrm{ha}^{-1}$ to both Kingbird and Hidase variety resulted in maximum marginal rates of return of $809.4 \%$ and $796.0 \%$, respectively. On the other hand, application of $100 \mathrm{~kg} \mathrm{NPSB} \mathrm{ha}^{-1}$ led to the highest MRR for the Huluka variety as compared to all other treatment, but a net benefit of 79789.1 Birr was obtained for the variety Huluka at $150 \mathrm{~kg} \mathrm{NPSB} \mathrm{ha-1}$ with about a $2746.8 \mathrm{NB}$ increment. Therefore, application of NPSB at the rate of $100 \mathrm{~kg} \mathrm{NPSB} \mathrm{ha}$ in the production of Kingbird and Hidase and $150 \mathrm{NPSB} \mathrm{kg} \mathrm{ha}^{-1}$ in the production of Huluka is economically beneficial.
\end{abstract}

Keywords: Blended, economic benefit, main effect, grain quality, grain yield

\section{INTRODUCTION}

Wheat is an important staple food crop all over the world [1]. It is one of the most important cereals cultivated in Ethiopia [2]. Ethiopia is one of the largest wheat producer in the Sub-Saharan Africa, with yearly estimated production of 4.5 million tons on 1.69 million hectares of land in 2016/17 [3] yield per hectares. Durum and bread wheat are the two major wheat species produced in the country. However, bread wheat surpasses durum wheat in recent years [4] due to its wide agro-ecological adaptation and better productivity.

Wheat is one of the major cereal crops in the Ethiopian highlands that lie between a latitude of $6^{\circ}$ and $16^{\circ} \mathrm{N}$ and longitude of $35^{\circ}$ and $42^{\circ} \mathrm{E}$ and is widely grown at an altitude range of 1500 to 3000 meters above sea level [5]. Wheat is also a leading source of vegetable protein in human food [6]. It is one of 
the daily diets of the Ethiopian population that contributes significantly to the calorie and protein intake. In terms of caloric intake, it is the second most important food in the country next to maize [7]. Wheat is one of the most important cereals cultivated in Arsi zone and ranks first in area coverage and total production. The total wheat area and production in the Arsi zone was 204,080.97 ha and 654899.47 tons, respectively, with the productivity of 3.209 tons $^{-1}{ }^{-1}$ in 2016/17 cropping season [3].

There are several factors that hindered wheat production in these areas such as low soil fertility, lack of improved wheat varieties and lack of improved management practices. The yield gap of Arsi zone over 3 tons $\mathrm{ha}^{-1}$, suggests the potential for increasing production through improved soil and crop management practices, particularly increased use of fertilizers and adequate soil fertility maintenance program. Continuous cropping and inadequate replacement of nutrients, removed in crop harvest or lose through erosion and leaching are the major causes of soil fertility decline in Ethiopia [8]. In the study area, wheat production is mainly constrained by both biotic and abiotic factors such as diseases especially rust, poor crop management practices, and poor soil fertility [9].

Among the above constraints, low soil fertility and slow progress in developing wheat cultivars with durable resistance to diseases are considered the most important constraints limiting wheat production in Ethiopia [10]. Thus, addition of nutrients such N, P, S and B to less fertile soil is important to increase wheat yield, yield components and grain quality of wheat whether it is for consumption or industrial purpose. Crop growth requires sufficient, but not excessive supply of essential mineral elements for optimal productivity. An insufficient supply of mineral elements may limit plant growth and development [11]. Several factors such as improved varieties, adequate cultural practices like balanced fertilization and management of other biotic and abiotic factors are very important for higher productivity of wheat [12]. Fertilizer is the most important input which contributes significantly towards final grain yield of wheat and to exploit the genetic potential of a cultivar [13].

For the last four to five decades, Ethiopian agriculture depended solely on imported fertilizer products; only urea and Di-ammonium phosphate (DAP), as sources of $\mathrm{N}$ and $\mathrm{P}$, respectively. However, recently it is perceived that the production of such high protein cereals like wheat can be limited by the deficiency of S and other nutrients [14]. It is true that farmers and extensionists can aim at increasing crop yields only in quantity by applying significantly higher amounts of NP from urea and DAP. But, in such conditions, failure to supplement $S$ in balanced-fertilizer programmes can rapidly deplete available soil reserve leading to hidden S deficiency [14]. Nitrogen is considered as the most deficient nutrients in soils of Ethiopia [15].

Nitrogen plays an important role in plant metabolism and all plant processes are related to nitrogen. If there is no enough amount of nitrogen fertilizer, the yield and quality of wheat will become worse and on the contrary, excessive nitrogen application will result in lower use efficiency of nitrogen in wheat and more environmental pollution [16]; [17]. Increasing $\mathrm{N}$ fertilizer greatly affected grain yield and quality of wheat protein content [18]. Adequate phosphorus enhances many aspects of plant physiology like photosynthesis, flowering, seed maturity and seed development [19]. Application of phosphorus stimulates root growth and photosynthesis [20]. Sulfur is an essential nutrient required to build yield and achieve grain quality. Nitrogen fertilizer may not be fully utilized if $S$ is deficient and correct $\mathrm{S}$ fertilization improves quality of grains. The capabilities of nitrogen fertilizer is to increase protein content, while sulfur fertilizer affects protein composition [21]. Boron is essential for cell division and elongation in meristematic tissues, floral organs and for flower male fertility, pollen tube germination along with its elongation and seed/fruit formation. Boron deficiency impairs grain setting in wheat, resulting in increased number of open spikelet's and decreased number of grains per spike [22].

Ethiopia is moving from blanket recommendations for fertilizer application rates to recommendations that are customized based on soil type and crop [23]. This is a move towards diversification and away from DAP and urea, which have long been the only types of fertilizer imported for grain crops. The prevailing blanket fertilizer rate recommendation through out the country on all soil types and agroecological zones justifies the existence of little information on the fertility status of Ethiopia's soils [24].

Varieties are one of the factors which play an important role in producing higher yield of wheat[12]. The three varieties of wheat Hidase, Huluka and Kingbird are selected based on their adaptability to the agro ecological conditions and rust disease resistance such as stem rust (Ug99) and yellow rust. 
Wise use of fertilizers increase crop yield and production; the reverse will lead to decline in production and ecological imbalance. Efficient use of fertilizers depends on performances of variety. So that cultivar selection plays a very important role in determining grain yield and quality [25]. A study was conducted to know the response of two wheat cultivars (Galama - HAR 604 and Sofumer HAR 1889) and four $\mathrm{N}$ rates $\left(30,60,90\right.$, and $\left.120 \mathrm{~kg} \mathrm{~N}^{-1}\right)$ at Kulumsa [26]. The result showed that variety Sofumer out smart Galama in grain yield at fertilizer rate of $30 \mathrm{~kg} \mathrm{~N} \mathrm{ha}^{-1}$.

Recent studies have indicated that elements like N, P, K, S and $\mathrm{Zn}$ levels as well as B and $\mathrm{Cu}$ are becoming depleted and deficiency symptoms are being observed on major crops in different areas of the country [27]. Most Ethiopian soils are deficit in macronutrients (N, P, K and S) and micronutrients $(\mathrm{Cu}, \mathrm{B}$, and $\mathrm{Zn})$ [28]. Macro-nutrients as well as micronutrients are of primary importance in our agriculture system but due to unawareness of the farmers about importance of applying micronutrients and unavailability, the soils are becoming deficient in micronutrients [29]. Micronutrients are essential for plant growth and play a vital role in increasing crop yields as they develop plant nutrition and increase soil efficiency [30].

The farmers in most parts of the country have limited information on the impact of different types and rates of fertilizers except blanket recommendation of nitrogen $\left(41 \mathrm{~kg} \mathrm{~N}^{-1}\right)$ and phosphorus $(46 \mathrm{~kg}$ $\mathrm{P}_{2} \mathrm{O}_{5}$ ha $^{-1}$ ), i.e. $50 \mathrm{~kg}$ Urea and $100 \mathrm{~kg}$ DAP per ha ${ }^{-1}$ for wheat while according to the soil fertility map made over 150 districts, most of the Ethiopian soils lack about seven nutrients (N, P, K, S, Cu, Zn and B) [31]. Except blanket recommendation of nitrogen and phosphorus, the effect of other fertilizers on yield components, yield, and grain quality of bread wheat are unknown, even though new blended fertilizers such as NPSB are currently available. Moreover, the response of wheat plant to application of fertilizer varies with varieties, rainfall, soils, agronomic practices, expected yield etc. Thus, there is a need to develop location specific recommendation on the fertilizer rates to increase the productivity as well as grain quality of wheat.

The increases in crop yields from application of $\mathrm{B}, \mathrm{Cu}, \mathrm{Fe}, \mathrm{Mn}, \mathrm{Mo}$, and $\mathrm{Zn}$ occur in many parts of the world [32]. The NPSB fertilizer rate and its effects on bread wheat yield and quality have not been studied extensively. The application of NPSB fertilizers to improve both yield and quality has become necessary in Ethiopia. Information is particularly lacking on effects of NPSB fertilizer rate on wheat yield and quality.

Therefore, this study was undertaken with the following objectives:

- to determine the effect of rates of blended NPSB on yield components, yield and grain quality of bread wheat varieties; and

- to estimate economically feasible rates of blended NPSB for bread wheat production.

\section{Materials AND Methods}

\subsection{Description of the Study Site}

The field experiment was conducted at Kulumsa Agricultural Research Center (KARC) from July to November 2017 under rain fed conditions. KARC represents mid-altitude production areas which is located at $08^{\circ} 05^{\prime} \mathrm{N}$ latitude and $39^{\circ} 10^{\prime} \mathrm{E}$ longitude at an altitude of $2200 \mathrm{~m}$ a.s.l, mean annual rainfall of $820 \mathrm{~mm}$, dark clay loam soil texture, soil $\mathrm{pH}$ of 6.0 and with mean minimum and maximum temperatures of $10.5^{\circ} \mathrm{C}$ and $22.8{ }^{\circ} \mathrm{C}$, respectively [33]. It is located in Arsi Administrative Zone of Oromia Regional State, $167 \mathrm{~km}$ South-east of Addis Ababa.

\subsection{Experimental Materials}

\subsubsection{Plant Materials}

Three bread wheat varieties (Hidase, Huluka, and Kingbird) were used as planting material. Those varieties are selected based on their adaptability to agro-ecological conditions of the area (Table 1).

Table1. Descriptions of the bread wheat varieties used in the experiment

\begin{tabular}{|c|c|c|c|c|c|c|}
\hline \multirow[t]{2}{*}{ No } & \multirow{2}{*}{$\begin{array}{l}\text { Varieties } \\
\text { name }\end{array}$} & \multirow{2}{*}{ Year of release } & \multicolumn{2}{|c|}{ Area of adaptation } & \multirow[t]{2}{*}{ Maturity days } & \multirow[t]{2}{*}{ On station productivity tons $\mathrm{ha}^{-1}$} \\
\hline & & & Altitude (m) & Rain fall (mm) & & \\
\hline 1. & Hidase & 2012 & $2200-2600$ & $500-800$ & 121 & $4.5-7.0$ \\
\hline 2. & Huluka & 2012 & $2200-2600$ & $500-800$ & 133 & $4.4-7.0$ \\
\hline 3. & Kingbird & 2015 & $1500-2200$ & $450-800$ & $95-105$ & $3.7-4.6$ \\
\hline
\end{tabular}

Source: [34] and [33] 


\subsubsection{Fertilizer Materials}

The blended NPSB fertilizer rates (18.9\% of $\mathrm{N}, 37.7 \%$ of $\mathrm{P}_{2} \mathrm{O}_{5}, 6.95 \%$ of $\mathrm{S}$ and $0.1 \%$ of $\mathrm{B}$ ) shown in Tegbaru [35] was used as the fertilizer source. The nitrogen source was urea $(46 \% \mathrm{~N})$ and was applied uniformly to all treatments except for zero.

\subsubsection{Soil Sampling and Analysis}

One representative soil sample was taken at a depth of 0-30 $\mathrm{cm}$ from five randomly selected spots diagonally across the experimental field using auger before planting. The sample was air dried under shade. One composite soil sample was submitted to the Ethiopian Construction Design and Supervision Works Corporation Research laboratory and training center in Addis Ababab for the analysis. The sample was ground using pestle and mortar and allowed to pass through a $0.5 \mathrm{~mm}$ for nitrogen, and in $2 \mathrm{~mm}$ sieve for others. The sample was analyzed for selected physico-chemical properties, namely organic carbon, texture, soil $\mathrm{pH}$, cation exchange capacity (CEC), total $\mathrm{N}$, available $\mathrm{P}, \mathrm{S}$ and $\mathrm{B}$.

Organic carbon was determined by Walkley and Black oxidation method[36]. Total nitrogen was analyzed by Kjeldhal method [37]. The $\mathrm{pH}$ of the soil was determined by potentiometric test method on 1: 2.5 (weight/volume) soils to water ratio using a $\mathrm{pH}$ meter[38]. The cation exchange capacity (CEC) was measured after saturating the soil with $1 \mathrm{~N}$ ammonium acetate $\left(\mathrm{NH}_{4} \mathrm{OAc}\right)$ and displacing it with $1 \mathrm{~N} \mathrm{NaOAc}$ [39]. Available phosphorus was determined by the Olsen method [40]. Available sulfur (mg/kg SO$\left.{ }_{4}^{-2}\right)$ was determined by ammonium acetate method[38]. Available B was determined using hot water method[41].

\subsection{Treatments and Experimental Design}

The experiment had 15 treatments in factorial combination of three improved bread wheat varieties (Hidase, Huluka and Kingbird) and four rates of NPSB fertilizers [0, 100, 150, 200 and NP (73/30) of local control] arranged in a randomized complete block design (RCBD) with three replications (Table 2). The gross plot size was 12 rows of three meter length $\left(3 \mathrm{~m} \times 2.4=7.2 \mathrm{~m}^{2}\right)$ with net harvestable rows of 10 with $2.5 \mathrm{~m}$ length $\left(2.5 \mathrm{~m} \times 2.0 \mathrm{~m}=5 \mathrm{~m}^{2}\right)$ were considered as net plot. The spacing between rows, plots and blocks were $0.20,0.5$ and $1 \mathrm{~m}$, respectively.

Table 2. Rates of fertilizer treatment used with their nutrient contents in $\mathrm{kg} \mathrm{ha}^{-1}$ for the experiment

\begin{tabular}{|l|l|l|l|l|l|}
\hline S. No & Fertilizer rates & $\mathbf{N}$ & $\mathbf{P}_{\mathbf{2}} \mathbf{O}_{\mathbf{5}}$ & $\mathbf{S}$ & $\mathbf{B}$ \\
\hline 1 & $0 \mathrm{~kg} \mathrm{NPSB}+0 \mathrm{~kg} \mathrm{~N} \mathrm{ha}^{-1}$ & 0 & 0 & 0 & 0 \\
\hline 2 & $100 \mathrm{~kg} \mathrm{NPSB}+73 \mathrm{~kg} \mathrm{~N} \mathrm{ha}^{-1}$ & 91.9 & 37.7 & 6.95 & 0.1 \\
\hline 3 & $150 \mathrm{~kg} \mathrm{NPSB}+73 \mathrm{~kg} \mathrm{~N} \mathrm{ha}^{-1}$ & 101.4 & 56.55 & 10.43 & 0.15 \\
\hline 4 & $200 \mathrm{~kg} \mathrm{NPSB}+73 \mathrm{~kg} \mathrm{~N} \mathrm{ha}^{-1}$ & 110.9 & 75.4 & 13.9 & 0.2 \\
\hline 5 & NP(73/30) as local control & 73 & 69 & 0 & 0 \\
\hline
\end{tabular}

\subsection{Experimental Procedures and Field Management}

The experimental field was ploughed with tractor and oxen to a fine tilth four times and the plots were leveled manually. Then, a field layout was made and each treatment was assigned randomly to the experimental units within a block. Bread wheat seed was sown at the recommended seed rate of 150 $\mathrm{kg} \mathrm{ha}^{-1}$ in rows of $20 \mathrm{~cm}$ spacing manually by drilling. The whole amount of blended (NPSB) was applied at sowing and the $2 / 3$ and $1 / 3$ of nitrogen was applied at the time of sowing and top-dressed at tillering respectively. Weeding was done as needed; and harvesting and threshing was done manually.

\subsection{Data Collection and Measurements}

- Days to 50\% heading (DTH) Days to spike heading was determined as the number of days taken from the date of sowing to the date of $50 \%$ heading of the plants from each plot by visual observation.

- Days to $90 \%$ physiological maturity (DTM) Days to physiological maturity was determined as the number of days from sowing to the date when $90 \%$ of the panincles turned to yellow straw color. It was recorded when no green color remained on glumes and panincles of the tagged plants, i.e. when grains are difficult to break with thumb nail.

- Plant height (PH) Plant height was measured from the soil surface to the tip of the spike (awns excluded) of 10 randomly tagged plants from the net plot area at physiological maturity. 
- Spike length (SL) It was measured from the bottom of the spike to the tip of the spike excluding the awns from 10 randomly tagged spikes from the net plot.

- Lodging percent (LP) The degree of lodging was assessed just before the time of harvest by visual observation based on the scales of $1-5$ where $1\left(0-15^{\circ}\right)$ indicates no lodging, $2\left(15-30^{\circ}\right)$ indicate $25 \%$ lodging, $3\left(30-45^{\circ}\right)$ indicate $50 \%$ lodging, $4\left(45-60^{\circ}\right)$ indicate $75 \%$ lodging and $5(60$ $90^{\circ}$ ) indicate $100 \%$ lodging[42]. The scales were determined by measuring the angle of inclination of the main stem from the vertical line to the base of the stem by visual observation. Data were normalized using Arcsine transformation.

- Number of total tillers (NTT) Number of total tillers per plant was determined from ten randomly pre-tagged plants per net plot at full tillering stage by counting the number of tillers and then the mean was determined.

- Number of productive tillers (NPT) Number of productive tillers was determined at maturity by counting all spikes bearing kernels from ten randomly pre-tagged plants per net plot at full tillering stage and then the mean was determined.

- Number of kernels per spike (NKS) Ten main tiller plants were taken randomly from the net plot area of each plot and number of kernels per spike was counted carefully and then the mean was determined.

- Thousand kernels weight (TKW) The TKW was determined by weighing 1000 kernels sampled from the net plot using a sensitive balance and the seed was adjusted to $12.5 \%$ moisture content.

- Aboveground dry biomass (AGB) The above ground dry biomass was determined from plants harvested from the net plot area after sun drying to a constant weight and converted to $\mathrm{kg}$ per hectare.

- Grain yield (GY) Grain yield was taken by harvesting and threshing the grain yield from net plot area. The grain yield was adjusted to $12.5 \%$ moisture content as:

Adjusted grain yield $=$ Grain yield obtained $\left(\mathrm{kg} \mathrm{ha}^{-1}\right) \times \underline{(100-\mathrm{MC})}$

$(100-12.5)$

Where MC- is the moisture content of bread wheat grains at the time of measurement and 12.5 is the standard moisture content of bread wheat in percent. Finally, yield per plot was converted to $\mathrm{kg} \mathrm{ha}^{-1}$

- Straw yield (SY) Straw yield was obtained by subtracting grain yield from the total above ground dry biomass yield for respective treatment and expressed in $\mathrm{kg} \mathrm{ha}^{-1}$.

- Harvest index (HI) Harvest index was calculated as ratio of grain yield per plot to total aboveground dry biomass yield per plot expressed as percent.

$$
\mathrm{HI}(\%)=\frac{\text { Grain yield }}{\text { Aboveground dry biomass }} \times 100
$$

- Hectoliter weight (HLW)It is the weight of flour density produced in a hectoliter of the seed and it was measured using a standard laboratory hectoliter weight apparatus at Kulumsa agricultural research center.

- Grain protein content (GP

- C) Grain protein content (GPC) was determined on a dry weight basis by near infrared reflectance spectroscopy (NIRS), by using "Infratec ${ }^{\mathrm{TM}} 1241$ Grain Analyzer" equipment at Food Science and Nutrition Laboratory of Kulumsa Agricultural Research Center. After calibrating the equipment for bread wheat, cleaned and prepared sample of $300 \mathrm{~g}$ seeds was added to the equipment and waited for one minute. Then the equipment read grain protein near infrared and displayed on screen.

\subsection{Data Analysis}

All data collected were subjected to analysis of variance (ANOVA) procedure using GenStat $\left(17^{\text {th }}\right.$ edition) software [43]. The comparisons among treatments means with significant difference for measured characters was done by LSD test at $5 \%$ level of significance.

\subsection{Economic Analysis}

The economic analysis was carried out by using the methodology described in [44] in which prevailing market prices for inputs at planting and for outputs at harvesting were used. All costs and 
benefits were calculated on hectare basis in Birr. The concepts used in the partial budget analysis were the mean grain yield of each treatment, the gross benefit (GB) ha ${ }^{-1}$ (the mean yield for each treatment) and the field price of fertilizers (the costs of NPSB and Urea and the application costs). The benefit of straw yield was included in the calculation of the benefit since the farmers of the study area use it. Marginal rate of return, which refers to net income obtained by incurring a unit cost of fertilizer and its application, was calculated by dividing the net increase in yield of bread wheat due to the application of each fertilizers rate. The net benefit (NB) was calculated as the difference between the gross field benefit and the total variable (TVC) using the formula

$\mathrm{NB}=\mathrm{GFB}-\mathrm{TVC}$

Where GFB $=$ Gross Field Benefit, TVC $=$ Total Variable Cost

Actual yield was adjusted downward by $10 \%$ to reflect the difference between the experimental yield and the yield farmers could expect from the same size field.

The dominance analysis procedure as described in CIMMYT was used to select potentially profitable treatments from the range that was tested. Any treatment that has higher TVC but net benefits that are less than or equal to the preceding treatment (with lower TVC but higher net benefits) is dominated treatment (marked as "D"). The dominance analysis illustrates that to improve farmers' income, it is important to pay attention to net benefits rather than yields, because higher yields do not necessarily mean high net benefits. The discarded and selected treatments using this technique were referred to as dominated and undominated treatments, respectively. For each pair of ranked treatments, $\%$ marginal rate of return (MRR) was calculated using the formula:

$$
\operatorname{MRR}(\%)=\frac{\text { Change in NB }(\mathrm{NBb}-\mathrm{NBa})}{\text { Change in TCV }(\mathrm{TVCb}-\mathrm{TVCa})} \times 100
$$

Where $\mathrm{NB}_{\mathrm{a}}=\mathrm{NB}$ with the immediate lower TCV, $\mathrm{NB}_{\mathrm{b}}=\mathrm{NB}$ with the next higher TCV, $\mathrm{TVC}_{\mathrm{a}}=$ the immediate lower TVC and $\mathrm{TVC}_{\mathrm{b}}=$ the next highest TCV.

The $\%$ MRR between any pair of undominated treatments was the return per unit of investment in fertilizer. To obtain an estimate of these returns, the \% MRR was calculated as changes in NB (raised benefit) divided by changes in cost (raised cost). Thus, a MRR of $100 \%$ implied a return of one Birr on every Birr spent on the given variable input.

The fertilizer cost was calculated for the cost of each fertilizer of NPSB (Birr $11.60 \mathrm{~kg}^{-1}$ ), TSP/P (Birr $40.00 \mathrm{~kg}^{-1}$ ) and N/UREA (Birr $9.42 \mathrm{~kg}^{-1}$ ) during sowing time. The cost of straw (Birr $0.2 \mathrm{~kg}^{-1}$ ), the cost of NPSB at sowing and Urea top dressing at tillering (Birr $210 \mathrm{ha}^{-1}$ ), respectively and the average open price of bread wheat at Asella market was Birr $14.00 \mathrm{~kg}^{-1}$ in January 2018 during harvesting time.

\section{RESUlTS AND DISCUSSION}

\subsection{Soil Physico-Chemical Properties of the Experimental Site}

According to the laboratory analysis, the soil texture of the experimental area is clay loam. The soil texture influences water contents, water intake rates, aeration, root penetration, and soil fertility. The $\mathrm{pH}$ of the soil was 6.56, which is slightly acidic according to [45]. [46] reported that the preferable $\mathrm{pH}$ ranges for most crops and productive soils are 4 to 8. [47] reported optimum pH range of 4.1 to 7.4 for wheat production. Thus, the $\mathrm{pH}$ of the experimental soil was within the range for productive soils. The analysis for other soil chemical properties indicated that the experimental soil had values of $0.21 \%$, $2.48 \%, 19.01 \mathrm{mg} \mathrm{P}_{2} \mathrm{O}_{5} \mathrm{~kg}^{-1}$ soil, $32.47 \mathrm{mg} \mathrm{kg}^{-1} \mathrm{SO}_{4}^{-2}, 0.67 \mathrm{mg} \mathrm{kg}^{-1} \mathrm{~B}$ soil, for total nitrogen, organic carbon, available phosphorous, available sulfur and available boron, respectively.

The fertility status of the area was good and it could be amended with the addition of recommended fertilizer rate. However, the low organic matter content of the soil could influence the release and availability of nutrients in the subsequent cropping season unless corrected properly (Table 3).

Table3. Selected physico-chemical properties of the soil of the experimental site before sowing

\begin{tabular}{|c|c|c|c|c|}
\hline No & Soil characters & Values & Rating & Reference \\
\hline 1. & $\begin{array}{ll}\text { Soil texture: } & \\
& \text { Sand (\%) } \\
& \text { Clay (\%) } \\
& \text { Silt (\%) }\end{array}$ & $\begin{array}{l}26.86 \\
36.02 \\
37.12\end{array}$ & & \\
\hline & Texture Class & Clay loam & & [48] \\
\hline
\end{tabular}


Effects of Blended (NPSB) Fertilizer Rates on Yield Components, Yield and Grain Quality of Bread Wheat (Triticum Aestivum L.) Varieties at Kulumsa, South-Eastern Ethiopia

\begin{tabular}{|l|l|l|l|c|}
\hline 2. & $\mathrm{pH}($ by $1: 2.5$ soil to water ratio) & 6.56 & Medium & {$[49]$} \\
\hline 3. & Organic carbon $(\%)$ & 2.48 & Low & {$[49]$} \\
\hline 4. & Total nitrogen $(\%)$ & 0.21 & Medium & {$[49]$} \\
\hline 5. & CEC (meq/100 g of soil) & 54.20 & Very high & {$[49]$} \\
\hline 6. & Available phosphorous $\left(\mathrm{mg} \mathrm{kg}^{-1}\right)$ & 19.01 & Medium & {$[50]$} \\
\hline 7. & Exch.K (meq/100 $\mathrm{g}$ of soil) & 2.7 & Excessive & {$[50]$} \\
\hline 8. & Available Sulfur $\left(\mathrm{mg} \mathrm{kg}^{-1}\right)$ & 32.47 & High & {$[50]$} \\
\hline 9. & Available Boron $\left(\mathrm{mg} \mathrm{kg}^{-1}\right)$ & 0.67 & Medium & {$[50]$} \\
\hline
\end{tabular}

Table4. Main effects of variety and blended fertilizer on Number of kernels per spike, thousand kernels weight, Aboveground biomass, and Grain yield of bread wheat

\begin{tabular}{|l|l|l|l|l|}
\hline Treatments & $\begin{array}{l}\text { Number of kernels } \\
\text { per spike }\end{array}$ & $\begin{array}{l}\text { Thousand kernel } \\
\text { weight }(\mathbf{g})\end{array}$ & $\begin{array}{l}\text { Aboveground } \\
\text { biomass }\left(\mathbf{k g ~ h a}^{-1}\right)\end{array}$ & $\begin{array}{l}\text { Grain yield } \quad(k g \\
\left.\text { ha }^{-1}\right)\end{array}$ \\
\hline Variety & & & & \\
\hline Hidase & $43.7^{\mathrm{b}}$ & $43.7^{\mathrm{a}}$ & $13200^{\mathrm{b}}$ & 5628 \\
\hline Huluka & $43.0^{\mathrm{b}}$ & $37.9^{\mathrm{b}}$ & $14080^{\mathrm{a}}$ & 5838 \\
\hline Kingbird & $47.1^{\mathrm{a}}$ & $40.1^{\mathrm{b}}$ & $11220^{\mathrm{b}}$ & 5423 \\
\hline LSD $(0.05)$ & 2.80 & 2.93 & 1851 & $\mathrm{NS}$ \\
\hline Fertilizer $\left(\mathrm{kg} \mathrm{ha}^{-1}\right)$ & & & & \\
\hline 0 & $43.3^{\mathrm{b}}$ & $38.1^{\mathrm{b}}$ & 11550 & $4866^{\mathrm{b}}$ \\
\hline $100 \mathrm{NPSB}$ & $44.7^{\mathrm{ab}}$ & $40.9^{\mathrm{ab}}$ & 13017 & $5934^{\mathrm{a}}$ \\
\hline $150 \mathrm{NPSB}$ & $48.3^{\mathrm{a}}$ & $43.8^{\mathrm{a}}$ & 13383 & $5848^{\mathrm{a}}$ \\
\hline $200 \mathrm{NPSB}$ & $43.0^{\mathrm{b}}$ & $39.7^{\mathrm{a}}$ & 13383 & $5565^{\mathrm{a}}$ \\
\hline $73 / 30 \mathrm{~N} / \mathrm{P}$ & $43.7^{\mathrm{ab}}$ & $40.4^{\mathrm{ab}}$ & 12833 & $5935^{\mathrm{a}}$ \\
\hline LSD $(0.05)$ & 4.94 & 5.07 & $\mathrm{NS}$ & 641 \\
\hline CV $(\%)$ & 8.1 & 9.1 & 15.9 & 8.3 \\
\hline
\end{tabular}

LSD $(0.05)=$ Least Significant Difference at $5 \%$ level; $C V=$ Coefficient of Variation; $N S=$ non-significant, Means in column followed by the same letters are not significantly different at $5 \%$ levels of Significance

\subsection{Number of Kernels Per Spike}

The result revealed that fertilizer showed significant $(p<0.05)$ effect with respect to the number of kernels per spike. While, the main effect of varieties had highly significant $(\mathrm{p}<0.01)$ effect on number of kernels per spike. However, the interaction between the two factors was not significant.

Variety Kingbird had the highest number of kernels per spike (47.1) while varieties Hidase and Huluka had significantly lower number of kernels per spike. The difference among varieties might be due genetic variability's among the varieties. In agreement with this result [51] reported that highly significant differences among the tested cultivars for number of kernels per spike with largest impact belongs to the genetic variability (63.92\%). Similarly, [52] observed significant differences among the wheat varieties for number of grains per spike. In contrast to this result [53] reported non significant difference among wheat cultivars for number of grains per spike in response to NPK fertilizer treatments which on an average varied only from 43.9 to 44.25 .

The effect of fertilizer also showed that the highest number of kernels per spike (48.3) was recorded from NPSB fertilizer rate of $150 \mathrm{~kg} \mathrm{ha}^{-1}$ (Table 4). Such response can be attributed to the adequate nitrogen availability which might facilitate the tillering ability of the plants, resulting in a greater spike population. These results agreed with the study by [54] who observed significant effects of nitrogen application on grain number per spike. Similarly [55] stating that number of grains per spike was significantly increased with each increment of NPK fertilizer. [56] also reported higher number of spikes per unit area at $120 \mathrm{~kg} \mathrm{~N} \mathrm{ha}^{-1}$ fertilized plots than the control.

\subsection{Thousand Kernels Weight (TKW)}

The result revealed that fertilizer rate showed significant $(\mathrm{p}<0.05)$ effect on the Thousand kernels weight and the varieties showed highly significant $(\mathrm{p}<0.01)$ difference while the interaction effect was not significant. Variety Hidase had the highest thousand kernels weight (43.7 g) whereas variety Huluka had the lowest thousand kernels weight (37.9 g) (Table 4). This might be due to good grain filling period and favourable environmental condition increases the thousand seed weights differ among the varieties. In line with this result the significant variation with the highest $42.96 \mathrm{~g}$ and lowest $39.58 \mathrm{~g}$ thousand seed weight among the varieties was reported by [57]. 
The effect of fertilizer rate showed that the highest thousand kernels weight (43.8 g) was recorded from NPSB fertilizer rate of $150 \mathrm{~kg} \mathrm{ha}^{-1}$ while the lowest thousand kernels weight $(38.1 \mathrm{~g})$ was obtained with no fertilizer application (Table 4). This may be due to the provision of balanced nutrients application have enhanced accumulation of assimilate in the grains and thus resulting in heavier grains of wheat. This could also be due to adequate and better nutrition of the plants resulted in good grain filling and development of better seed size. The fact that higher amount of nitrogen application resulted in higher percentage of weight gain in grain filling stage in kernels and there by thousand kernel weight increased [58]. [59] also reported that 1000 kernels weight increased with the increase in nitrogen rate up to $100 \mathrm{~kg} \mathrm{ha}^{-1}$. In similar to this result, [60] also reported that increasing $\mathrm{N}$ rate from $92 \mathrm{~kg} \mathrm{~N} \mathrm{ha}^{-1}$ to $138 \mathrm{~kg} \mathrm{~N} \mathrm{ha}^{-1}$ decreased thousand kernels weight of bread wheat by about $3.7 \%$.

\subsection{Above Ground Biomass ( Kg Ha-1)}

Analysis of variance showed that the main effect of variety had a highly significant effect $(p<0.01)$ on aboveground dry biomass yield. On the other hand, the main effect of fertilizer rate and the interaction effect of variety and fertilizers were not significant. Variety Huluka produced the highest aboveground dry biomass yield $\left(14080 \mathrm{~kg} \mathrm{ha}^{-1}\right)$ while the lowest biomass $\left(11220 \mathrm{~kg} \mathrm{ha}^{-1}\right)$ was produced from variety Kingbird (Table 4). This might be due to increase in number of tillers per plant, increase length of leaves and due to increase in vegetative growth of the plants.

Though the difference was statistically non-significant, the aboveground dry biomass was increased as the rate of NPSB increased from 0 to $200 \mathrm{~kg} \mathrm{ha}^{-1}$ (Table 4). The increase in aboveground dry biomass at the highest rates of NPSB might have resulted from improved root growth and increased uptake of nutrients favoring better growth and delayed senescence of leaves of the crop due to synergetic effect of the nutrients.

In conformity with this result, [61] reported vegetative growth and biological yield has much dependence to consumption of chemical fertilizers, application of the fertilizers led to increasing biological yield of wheat. Similarly, [62] also reported that increasing N rates from 23 to $69 \mathrm{~kg} \mathrm{ha}^{-1}$ increased aboveground dry biomass of wheat by about 22.6\%. Likewise, [63] stated that supply of $\mathrm{P}_{2} \mathrm{O}_{5}$ at rate of $69 \mathrm{~kg} \mathrm{ha}^{-1}$ in wheat found to be adequate to produce maximum aboveground dry biomass. [64] also reported the maximum aboveground dry biomass of wheat have obtained with application of $140 \mathrm{~kg} \mathrm{~N} \mathrm{ha}^{-1}$ at sowing and $20 \mathrm{~kg} \mathrm{~S} \mathrm{ha}^{-1}$ at anthesis.

\subsection{Grain Yield ( Kg Ha-1)}

The result regarding grain yield showed highly significant $(\mathrm{p}<0.01)$ differences in grain yield among fertilizer rates and not significant differences among wheat varieties and the interaction of fertilizer rate and varieties. Thus, the highest grain yield $\left(5935 \mathrm{~kg} \mathrm{ha}^{-1}\right)$ was obtained at the rates of $73 \mathrm{~kg} \mathrm{~N}$ and $30 \mathrm{~kg} \mathrm{P} \mathrm{ha}{ }^{-1}$ whereas, the lowest grain yield $\left(4866 \mathrm{~kg} \mathrm{ha}^{-1}\right)$ was recorded at no fertilizer application (Table 4).

The increase in grain yield at NP rate might have resulted from improved root growth and increased uptake of nutrients and better growth favored due to the synergetic effects of both nutrients which enhanced yield components and yield. In agreement with this result, [65] found that increasing $\mathrm{N}$ rate from 0 to $120 \mathrm{~kg} \mathrm{~N}^{-1}{ }^{-1}$ increased grain yield of bread wheat. [60] also reported that increasing $\mathrm{P}$ rate from 46 to $69 \mathrm{~kg} \mathrm{P}_{2} \mathrm{O}_{5} \mathrm{ha}^{-1}$ increased grain yield of bread wheat by about 6.8\%. Similarly, [66] reported that application of nutrients like $\mathrm{K}, \mathrm{S}, \mathrm{Zn}, \mathrm{Mg}$ and $\mathrm{B}$ used in experiments significantly increased grain yield and yield component of bread wheat as compare to the control (no fertilizer).

Table5. Main effects of variety and blended fertilizer on straw yield, harvest index. Hectoliter weight and Grain protein content of bread wheat

\begin{tabular}{|l|l|l|l|l|}
\hline Treatments & $\begin{array}{l}\text { Straw yield } \\
\left(\mathbf{k g ~ h a}^{-1}\right)\end{array}$ & Harvest index $\mathbf{( \% )}$ & $\begin{array}{l}\text { Hectoliter weight } \\
\left(\mathbf{k g ~ h L}^{-\mathbf{1}}\right)\end{array}$ & $\begin{array}{l}\text { Grain } \\
\text { content }(\%)\end{array}$ \\
\hline Variety & & & & \\
\hline Hidase & $7573 \mathrm{a}$ & $43.5^{\mathrm{b}}$ & 82.2 & $16.2^{\mathrm{a}}$ \\
\hline Huluka & $8242 \mathrm{a}$ & $42.0^{\mathrm{b}}$ & 82.6 & $15.2^{\mathrm{b}}$ \\
\hline Kingbird & $5797^{\mathrm{b}}$ & $48.5^{\mathrm{a}}$ & 82.3 & $15.2^{\mathrm{b}}$ \\
\hline LSD $(\mathbf{0 . 0 5})$ & 1616 & 4.67 & $\mathrm{NS}$ & 0.59 \\
\hline
\end{tabular}


Effects of Blended (NPSB) Fertilizer Rates on Yield Components, Yield and Grain Quality of Bread Wheat (Triticum Aestivum L.) Varieties at Kulumsa, South-Eastern Ethiopia

\begin{tabular}{|l|l|l|l|l|}
\hline Fertilizer $\left(\mathbf{k g ~ h a}^{-1}\right)$ & & & & \\
\hline 0 & 6684 & 42.7 & $81.7^{\mathrm{b}}$ & $16.2^{\mathrm{a}}$ \\
\hline $\mathbf{1 0 0}$ NPSB & 7082 & 46.7 & $82.9^{\mathrm{a}}$ & $14.9^{\mathrm{c}}$ \\
\hline $\mathbf{1 5 0}$ NPSB & 7535 & 44.5 & $82.9^{\mathrm{a}}$ & $15.1^{\mathrm{bc}}$ \\
\hline $\mathbf{2 0 0}$ NPSB & 7818 & 42.2 & $82.0^{\mathrm{ab}}$ & $15.9^{\mathrm{ab}}$ \\
\hline $\mathbf{7 3 / 3 0}$ N/P & 6899 & 47.3 & $82.5^{\mathrm{ab}}$ & $15.7^{\mathrm{abc}}$ \\
\hline LSD (0.05) & $\mathrm{NS}$ & $\mathrm{NS}$ & 1.03 & 0.90 \\
\hline CV (\%) & 24.8 & 11.6 & 0.91 & 4.22 \\
\hline
\end{tabular}

LSD (0.05) = Least Significant Difference at 5\% level; $C V=$ Coefficient of Variation; NS= non-significant, Means in column followed by the same letters are not significantly different at 5\% levels of Significance

\subsection{Straw Yield}

The result showed highly significant $(\mathrm{P}<0.01)$ difference among the varieties of wheat on straw yield while the fertilizer rate and the interaction between the two factors were not-significant. Variety Huluka had the highest straw yield $\left(8242 \mathrm{~kg} \mathrm{ha}^{-1}\right)$ whereas variety Kingbird had the lowest straw yield $\left(5797 \mathrm{ka} \mathrm{ha}^{-1}\right)$ (Table 5). This might be due to varying response of varieties to fertilizer application or differences in genetic make-up of the varieties. Similarly, [67] and [68] found that straw yield of wheat significantly varied among the varieties.

The result showed that an increase in straw yield when fertilizer rate increased from the lowest to the highest rate. The highest straw yield of $7818 \mathrm{~kg} \mathrm{ha}^{-1}$ was obtained at the highest NPSB rate of $200 \mathrm{~kg}$ $\mathrm{ha}^{-1}$ whereas the lowest straw yields of $6684 \mathrm{~kg} \mathrm{ha}^{-1}$ was from the control(Table 5). The significant increase in straw yield in response to the highest rate of blended NPSB might be attributed to the synergistic roles of the nutrients that enhanced growth and development of the crop. The result is consistent with that of [69] who reported increased straw yield of wheat with increase in NP fertilizers rates up to $90 / 45 \mathrm{~kg} \mathrm{ha}^{-1}$. [60] also reported that the highest straw yield was recorded at the highest nitrogen rate of $69 \mathrm{~kg} \mathrm{~N} \mathrm{ha}^{-1}$. Similarly, [68] reported that higher nitrogen application (160 $\left.\mathrm{kg} \mathrm{ha}^{-1}\right)$ has more contribution in higher straw yield production $\left(9098.65 \mathrm{~kg} \mathrm{ha}^{-1}\right)$ as compared to control treatment $\left(5302.97 \mathrm{~kg} \mathrm{ha}^{-1}\right)$.

\subsection{Harvest Index (HI)}

Harvest Index $(\mathrm{HI})$ was highly significantly $(\mathrm{p}<0.01)$ affected by varieties. But the fertilizer rate and the interaction between the two factors were non-significant. Harvest index shows the efficiency of the distribution of photosynthetic materials between different plant organs. Variety Kingbird gave the highest $\mathrm{HI}$ of $48.5 \%$ as compared to varieties Hidase and Huluka which gave significantly lowest $\mathrm{HI}$ (Table 5). Harvest indices of the varieties, averaged across all treatments, varied [70]. As to the other experiment, non-significant effect of $\mathrm{N}$ supply on harvest index has been reported for wheat [71].

\subsection{Hectoliter Weight (HLW)}

The result showed a highly significant $(\mathrm{p}<0.01)$ effect of fertilizer rates on Hectoliter weight, while the effect of varieties and their interactions were non-significant. The highest HLW was obtained from the NPSB fertilizer rate of $100 \mathrm{~kg} \mathrm{ha}^{-1}$ and $150 \mathrm{~kg} \mathrm{ha}^{-1}$, as compared to the other fertilizer rate of $0 \mathrm{~kg}$ NPSB ha ${ }^{-1}$ (Table 5). Significantly higher HLW with the application of blended NPSB rate might be due to the role of balanced nutrients on quality of wheat such as flour yield [72]. This result is in line with that of [73] who reported that hectoliters weight increased significantly with application of NPK fertilizer and was the highest with application of $125 \mathrm{~kg} \mathrm{NPK} \mathrm{ha}^{-1}$. The increase in the level of applied $\mathrm{N}$ also increased hectoliter weight of the wheat grain[74]. [75] also indicated that hectoliter weight ranged from about $57.9 \mathrm{~kg} \mathrm{hL}^{-1}$ for poor wheat and to about $82.4 \mathrm{~kg} \mathrm{hL}^{-1}$ for sound wheat. The current result indicated hectoliter weight ranged from 81.7 to $82.9 \mathrm{~kg} \mathrm{hL}^{-1}$ which is in good quality range.

\subsection{Grain protein content (\%)}

Grain protein content was significantly $(\mathrm{p}<0.01)$ affected by fertilizer rate and varieties, but the interaction between the two factors was non-significant. Variety Hidase gave the highest GPC of $16.2 \%$ whereas varieties Huluka and Kingbird gave significantly lower GPC of 15.2\% (Table 5). The variation in grain protein content of the varieties may be attributed to their variation in nutrient uptake and translocation capacities to the sink. In line with this result, [76] concluded that the grain quality and physical properties of the different wheat varieties examined were strongly influenced by the cultivars. 
Effects of Blended (NPSB) Fertilizer Rates on Yield Components, Yield and Grain Quality of Bread Wheat (Triticum Aestivum L.) Varieties at Kulumsa, South-Eastern Ethiopia

With respect to the effect of fertilizer, the maximum GPC of $16.2 \%$ was recorded from control and it was statisticaly at per with $200 \mathrm{~kg}$ NPSB ha ${ }^{-1}$ and 73/30 NP while $100 \mathrm{~kg} \mathrm{NPSB} \mathrm{ha}^{-1}$ gave the lowest GPC of $14.9 \%$ (Table 5). The lower GPC at the highest NPSB rate may be due to high amount of N component fertilizer applications causes lodging as a result the quality of the crop decreased. This is supported by the soil analysis result prior to planting where medium amount of nitrogen and high amount of available sulfur content were recorded in the field (Table 3). The result is in agreement with [77] who reported that over supply of $\mathrm{N}$ may cause lodging, disease incidence and lower grain quality. Adequate nitrogen supply improves protein content of vegetative organs as well as storage tissues and manufactures protein from carbohydrates[78]. Mature wheat grains contain 8-20\% proteins[79]. [80] reported higher GPC in all three experiments: $14 \%$ in the $\mathrm{N}$ rate experiment; $14.7 \%$ in the fertilizer timing and splitting experiment and $16.2 \%$ in the type of fertilizer experiment. [81] also reported the protein content in wheat grains ranged from $9.23 \%$ to $15.11 \%$.

\subsection{Partial Budget Analysis}

Partial budget analysis is important to identify experimental treatments with an optimum return to the farmer's investment and to develop recommendation for the agronomic data. Experimental yields are often higher than the yields that farmers could expect using the same treatments; hence in economic calculations, yields of farmers are adjusted by $10 \%$ less than that of the research results [44]. As indicated in Table 6, the partial budget analysis showed that highest net benefit of (79789.1) Birr ha ${ }^{-1}$ was obtained for variety Huluka that received $150 \mathrm{~kg} \mathrm{NPSB} \mathrm{ha}^{-1}$. However, the lowest net benefits of (58479.3) Birr ha $^{-1}$ were obtained from the unfertilized treatment with the variety Kingbird.

In this study, Huluka varieties gave economic benefit of $\left(77042.4 \mathrm{ha}^{-1}\right)$ with marginal rate of return $(664.1 \%)$ at $100 \mathrm{~kg} \mathrm{NPSB} \mathrm{ha}^{-1}$ fertilizer rate but economic benefit of $\left(79789.1 \mathrm{ha}^{-1}\right)$ Birr was obtained for the variety Huluka at $150 \mathrm{~kg}$ NPSB ha ${ }^{-1}$ with about a (2746.8) net benefit increment. whereas, in case of both varieties namely Hidase and Kingbird at $100 \mathrm{~kg}$ NPSB ha ${ }^{-1}$ fertilizer rate gave the maximum economic benefit $\left(75092.1 \mathrm{ha}^{-1}\right)$ with marginal rate of return $(796.0 \%)$ and maximum economic benefit $\left(71267.8 \mathrm{ha}^{-1}\right)$ with marginal rate of return $(809.4 \%)$, respectively. According to [44] suggestion, the minimum acceptable marginal rate of return should be more than $100 \%$. The results of this study indicated that an application of NP $\mathrm{kg} \mathrm{ha}^{-1}$ to both varieties Huluka and Kingbird gave un acceptable range with marginal rate of return $(58.1 \%)$ and $(76.9 \%)$, respectively.

Therefore, the two varieties Hidase and Kingbird at $100 \mathrm{~kg} \mathrm{NPSB} \mathrm{ha}^{-1}$ and for Huluka varieties at 150 $\mathrm{kg}$ NPSB ha ${ }^{-1}$ were economical and recommended for production of Bread wheat in the study area and other areas with similar agro ecological condition. In line with this result, [18] recommended $92 \mathrm{~kg} \mathrm{~N}$ $\mathrm{ha}^{-1}$ and $46 \mathrm{~kg} \mathrm{P}_{2} \mathrm{O}_{5} \mathrm{ha}^{-1}$ for production of wheat for moist and humid midland vertosols areas of Arsi zone. [62] also reported that $\mathrm{N}$ application at $69 \mathrm{~kg} \mathrm{ha}^{-1}$ is effective in attaining higher grain yield and economic benefit of wheat in southern part of Ethiopia.

Table6. Summary of economic analysis of the effects of blended fertilizer (NPSB) rates on bread wheat varieties at Kulumsa in 2017 cropping season

\begin{tabular}{|c|c|c|c|c|c|c|c|c|c|}
\hline \multicolumn{2}{|c|}{ Treatments } & \multirow{2}{*}{$\begin{array}{c}\text { AGY } \\
\left(\mathrm{kg} \mathrm{ha}^{-1}\right)\end{array}$} & \multirow{2}{*}{$\begin{array}{c}\text { ASY } \\
\left(\mathrm{Kg} \mathrm{ha}^{-1}\right)\end{array}$} & \multicolumn{2}{|c|}{$\begin{array}{l}\text { Income (ETB ha } \\
\mathbf{1}^{-}\end{array}$} & \multirow{2}{*}{$\begin{array}{c}\text { Gfb } \\
\left(\begin{array}{c}\text { Etb } \mathbf{H a}^{-} \\
\text {1) }\end{array}\right.\end{array}$} & \multirow{2}{*}{$\begin{array}{c}\text { Tvc(Etb } \\
\left.\mathbf{H a}^{-1}\right)\end{array}$} & \multirow{2}{*}{$\begin{array}{c}\mathrm{Nb}(\mathbf{E t b} \\
\left.\mathbf{H a}^{-1}\right)\end{array}$} & \multirow[t]{2}{*}{$\begin{array}{c}\text { MRR } \\
(\%)\end{array}$} \\
\hline Varieties & Fertilizers & & & Grain & Straw & & & & \\
\hline Hidase & 0 & 4379.4 & 6015.6 & 61311.6 & 1203.1 & 62514.7 & 0 & 62514.7 & \\
\hline Hidase & 100 & 5376.6 & 6998.4 & 75272.4 & 1399.7 & 76672.1 & 1580 & 75092.1 & 796.0 \\
\hline Hidase & 150 & 4970.7 & 6414.3 & 69589.8 & 1282.9 & 70872.7 & 2160 & 68712.7 & $\mathrm{D}$ \\
\hline Hidase & 200 & 5022.9 & 7847.1 & 70320.6 & 1569.4 & 71890.0 & 2740 & 69150.0 & 75.4 \\
\hline Hidase & NP & 5573.7 & 6801.3 & 78031.8 & 1360.3 & 79392.1 & 4523.6 & 74868.5 & 320.6 \\
\hline Huluka & 0 & 4650.3 & 7229.7 & 65104.2 & 1445.9 & 66550.1 & 0 & 66550.1 & 183.9 \\
\hline Huluka & 100 & 5525.1 & 6354.9 & 77351.4 & 1270.9 & 78622.4 & 1580 & 77042.4 & 664.1 \\
\hline Huluka & 150 & 5730.3 & 8624.7 & 80224.2 & 1724.9 & 81949.1 & 2160 & 79789.1 & 473.6 \\
\hline Huluka & 200 & 5077.8 & 7792.2 & 71089.2 & 1558.4 & 72647.6 & 2740 & 69907.6 & $\mathrm{D}$ \\
\hline Huluka & NP & 5289.3 & 7085.7 & 74050.2 & 1417.1 & 75467.3 & 4523.6 & 70943.7 & 58.1 \\
\hline Kingbird & 0 & 4108.5 & 4801.5 & 57519 & 960.3 & 58479.3 & 0 & 58479.3 & 275.5 \\
\hline Kingbird & 100 & 5121 & 5769 & 71694 & 1153.8 & 72847.8 & 1580 & 71267.8 & 809.4 \\
\hline Kingbird & 150 & 5089.5 & 5305.5 & 71253 & 1061.1 & 72314.1 & 2160 & 70154.1 & $\mathrm{D}$ \\
\hline Kingbird & 200 & 4924.8 & 5470.2 & 68947.2 & 1094.0 & 70041.2 & 2740 & 67301.2 & $\mathrm{D}$ \\
\hline Kingbird & NP & 5160.6 & 4739.4 & 72248.4 & 947.9 & 73196.3 & 4523.6 & 68672.7 & 76.9 \\
\hline
\end{tabular}


Where, $A G Y=$ adjusted grain yield $; A S Y=$ adjusted straw yield; $G F B=$ gross field benefit; TVC = total variable costs; $N B=$ net benefit, MRR = marginal rate of return; ETB ha ${ }^{-1}=$ Ethiopian Birr per hectare; $D=$

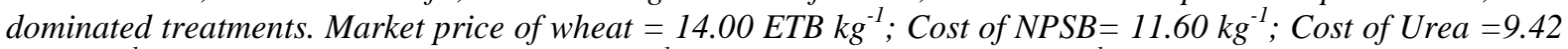

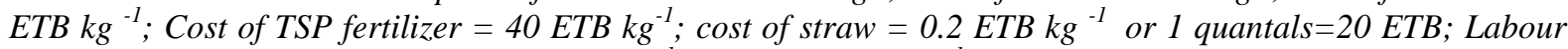
cost for fertilizer application $=6$ persons $\mathrm{ha}^{-1}$, each $35 \mathrm{ETB}_{\text {day }}{ }^{-1}$; Labour cost for urea top dress fertilizer application at tillering $=6$ person $\mathrm{ha}^{-1}$, each $35 \mathrm{ETB}_{\mathrm{day}}{ }^{-1}$.

\section{Summary AND Conclusions}

In Ethiopian recently it is perceived that the production of such high protein cereals like wheat can be limited by the deficiency of $\mathrm{S}$ and other nutrients. Thus, addition of nutrients such $\mathrm{N}, \mathrm{P}, \mathrm{S}$ and $\mathrm{B}$ to low fertile soil is important to increase yield, yield components and quality of wheat whether it is for consumption or industrial purpose. The results regarding to partial budget analysis showed that, 150 $\mathrm{kg}$ NPSB ha- fertilizer application was found to be economically beneficial with net benefit of 79789.1 Birr ha ${ }^{-1}$ with MRR of $473.6 \%$ for Huluka varieties compared to the other treatments in the study area. Therefore, application of NPSB at the rate of $100 \mathrm{~kg} \mathrm{NPSB} \mathrm{ha}^{-1}$ in the production of Kingbird and Hidase and 150 NPSB kg ha ${ }^{-1}$ in the production of Huluka is economically beneficial.

\section{REFERENCES}

[1] Mathpal B., Srivastava P.C. , D. Shankhdhar, S. C. S. 2015. Zinc enrichment in wheat genotypes under various methods of zinc application. Plant, Soil and Environment, 61(4):171-175.

[2] Jemal Abdulkerim, Tamado Tana and Firdissa Eticha. 2015. Response of Bread Wheat (Triticum aestivum L.) Varieties to Seeding Rates at Kulumsa, South Eastern Ethiopia. Asian Journal of Plant Sciences, 14(2):50-58.

[3] CSA (Central Statistical Agency). 2017. Agricultural sample survey: area and production of major crops, Meher season. Vol. I. Addis Ababa, Ethiopia.

[4] Eshetu Bekele and Zerihun Kassaye. 2003. Integrated management of Septoria blotches of wheat: Effect of sowing date, variety and fungicide. Pest Management Journal of Ethiopia, 7:11-18.

[5] Tanner D., Amanuel Gorfu and Asefa Tilahun. 1993. Fertilizer effect on sustainability in the Wheat based smallholder farming systems of southeastern Ethiopia. Field Crops Research, 33:235-248.

[6] Yong Li, Yanping Yin, Qi Zhao, and Z. W. 2011. Changes of Glutenin Subunits due to Water-Nitrogen Interaction Influence Size and Distribution of Glutenin Macropolymer Particles and Flour Quality. Crop Science, 51:2809-2819.

[7] FAO. 2014. World reference base for soil resources. United Nations, Rome.

[8] Hillette Hailu, Tekalign Mamo, R. Keskinen, E. Karltun, Heluf Gebrekidan and Taye Bekele. 2015. Soil fertility status and wheat nutrient content in Vertisol cropping systems of central highlands of Ethiopia. Agriculture and Food Secure. 4:19-23.

[9] Demeke, M. and Di Marcantonio F. 2013. Analysis of incentives and disincentives for wheat in Ethiopia. Technical notes series, MAFAP, FAO, Rome.

[10] Teklu Erkossa and Teklewold Hailemariam. 2009. Agronomic and economic efficiency of manure and urea fertilizers use on vertisols in Ethiopian Highlands. Agricultural Sciences in China, 8(3):352-360.

[11] Nadian H. , Najarzadegan R., Alami Saeid K., M. H. G. and A. S. 2010. Effects of Boron and Sulfur Application on Yield and Yield Components of Brassica napus L . in a Calcareous Soil. World Applied Sciences Journal, 11(1):89-95.

[12] Alam, M. S. and Jahan, I. 2013. Yield and yield components of wheat as affected by phosphorus fertilization. Rajshahi University Journal of Life and Earth and Agricultural Sciences, 41:21-27.

[13] Kaleem, S., Ansar, M., Ali, M. A., Sher, A., Ahmad, G., and Rashid, M. 2009. Effect of Phosphorus on the Yield and Yield Components of Wheat Variety " Inqlab-91 " Under Rainfed Conditions. Sarhad Journal of Agriculture, 25(1):1989-1992.

[14] Assefa M., Johnson M. R. Semoka, N. A. and Tekalign M. 2015. Wheat Response to Applied Nitrogen , Sulfur, and Phosphorous in three Representative Areas of the Central Highlands of Ethiopia-I. International Journal of Plant \& Soil Science, 8(5):1-11.

[15] Asnakew, W., Tarekegn, M., Mengesha, B., and Tefera, A.1991. "Soil fertility management studies on wheat in Ethiopia." Wheat Research in Ethiopia: A Historical Perspective. Addis Ababa, IAR/CIMMYT: 137-172.

[16] Dogan, R. and U.Bilgili, 2010. Effects of previous crop and N-fertilization on seed yield of winter wheat (Triticum aestivum L.) under rain-fed Mediterranean conditions. Bulgarian Journal of Agricultural Science, 16:733-739.

[17] Liu, D. and Y. Shi, . 2013. Effects of different nitrogen fertilizer on quality and yield in winter wheat. Advance Journal of Food Science and Technology, 5(5):646-649. 
[18] Dawit Hapte, Kasu Tadese, Wubengeda Admasu, Tadese Dessalegn and Asrat Mekonen. 2015. Agronomic and Economic Evaluation of the $\mathrm{N}$ and $\mathrm{P}$ Response of Bread Wheat Grown in Moist and Humid Midhighland Vertisols Areas of Arsi Zone, Ethiopia. African Journal of Agricultural Research, 10(3):89-99.

[19] Ziadi, N., G. Belander, A. N. Cambouris, N. Trembly, M. C. Nolinand A. Claessens, 2008. Relationship between phosphorus and nitrogen concentartions in spring wheat. Agronomy Journal, 100(1):80-86.

[20] Singh, D.K. and P.W.G. Sale. 2000. Growth and potentially conductivity of white clover roots in dry soil with increasing phosphorus supply and defoliation frequency. Agronomy Journal, 92:868-874.

[21] Luo, C., Branlard, G., Griffin, W. B. and McNeil, D. L. 2000. The effect of nitrogen and sulphur fertilisation and their interaction with genotype on wheat glutenins and quality parameters. Journal of Cereal Science, 31:185-194.

[22] Marschner, H. 1995. Mineral nutrition of higher plants. $2^{\text {nd }}$ Ed. New York: Academic Press, pp: 889.

[23] Nicholas Minot, J. W., Solomon Lemma, Leulsegged Kasa, A. G. and S. R. 2015. The Wheat Supply Chain in Ethiopia: Patterns, trends, and policy options. Washington, DC. https://doi.org/International Food Policy Research Institute, Markets, Trade, and Institutions Division n.minot@cgiar.org (Accessed on February 11, 2017).

[24] Dagne Chimdessa. 2016. Blended Fertilizers Effects on Maize Yield and Yield Components of Western Oromia, Ethiopia. Agriculture, Forestry and Fisheries, 5(5):151-162.

[25] Brian N. Otteson, Mohamed Mergoum and J. K. R. 2007. Seeding rate and nitrogen management effects on spring wheat yield and yield components. Agronomy Journal, 99(6):1615-1621.

[26] Genene Gezu. 2003. Yield and Quality Response of Bread Wheat (Triticum aestivum L.) Varieties to rate and time of Nitrogen fertilizer application in Kulumsa, Southeastern Ethiopia. Alemaya.

[27] ATA (Agricultural Transformation Agency) 2013. Status of soil resources in Ethiopia and priorities for sustainable management. Ethiopian agricultural transformation agency In: Global Soil partnership (GSP) for eastern and southern Africa. March 25-27:2013, Nairobi, Kenya. (http://www.fao.org/ fileadmin/user_upload/GSP/docs/Southeast partnership/Ethiopia.pdf) (Accessed on February 11, 2017).

[28] EthioSIS (Ethiopian Soil Information System). 2014. Soil Fertility and Fertilizer recommendation Atlas of Tigray Region. Ministry of Agriculture (MoA) and Agricultural Transformation Agency (ATA).

[29] Muhammad Tahir, Asif Tanveer, Tajamal Hussain Shah, Naeem Fiaz and Allah Wasaya .2009. Yield Response of Wheat (Triticum aestivum L.) to Boron Application at Different Growth Stages. Pakistan journal of life and social science, 7(1):39-42.

[30] Hamzeh Mohmmed. Rawashdeh and Florin Sala. 2013. The effect of foliar application of iron and boron on early growth parameters of wheat (Triticum aestivum L.). Research Journal of Agricultural Science, 45(1):21-26.

[31] EthioSIS (Ethiopian Soil Information System). 2013. Soil analysis report. Agricultural Transformation Agency (Unpublished).

[32] Martens, D.C. and Westermann, D. T. 1991. Fertilizer Applications for Correcting Micronutrient Deficiencies. Soil Science Society of America, 677 S. Segoe Rd., Madison, WI 53711, USA. Micronutrients in Agriculture. $2^{\text {nd }}$ ed. SSSA Hook Series, no. 4.pp. 549-553.

[33] KARC (Kulumsa Agricultural Research Center). 2000. Kulumsa Agricultural Research Center laboratory manual.

[34] MoA (Ministry of Agriculture). 2012. Ministry of Agriculture. Animal and Plant Health Regulatory Directorate. Crop variety register, Issue No. 15. Addis Ababa, Ethiopia.

[35] Tegbaru Bellete. 2015. Soil fertility mapping and fertilizer recommendation in Ethiopia:update of EthioSIS project and status of fertilizer blending plants. $2^{\text {nd }}$ IPI-MoANR-ATA-Hawassa University joint symposium.

[36] Walkley, A.J. and Black, I.A. 1934. Estimation of soil organic carbon by the chromic acid titration method. Soil Science, 37:29-38.

[37] Dewis, J. and Freitas, P. 1975. Physical and chemical methods of soil and analysis. FAO Bulletin No. 10. Rome. 175p.

[38] Motsara, M.R. and. Roy, R.N. 2008. Guide to laboratory establishment for plant nutrient analysis. FAO Fertilizer and Plant Nutrition Bulletin 19. Rome.

[39] Chapman, H. D. 1965. Cation exchange capacity by ammonium saturation. 891-901. In: Black, C.A., L.E. Ensminger and F.E. Clark (ed.), Method of soil analysis. American Society of Agronomy, Madison Wisconsin, USA.

[40] Olsen S. R.,. Cole, C.W.,Watanabe F.S. and Dean, L.A. 1954. Estimation of available phosphorous in soils by extraction with sodium bicarbonate. Soil Science, 96:308-312. 
[41] Havlin, J.L., Beaton J.D., Tsdale, S.L., nelson W.L. 1999. Soil fertility and fertilizer: an introduction to nutrient management Prentice Hall, New York, 499p.

[42] Donald, L.S. 2004. Understanding and reducing lodging in cereals. Advances in Agronomy, 84:217-271.

[43] GenStat. 2014. GenStat Procedure Library Release. $17^{\text {th }}$ edition. VSN International Ltd.

[44] CIMMYT (Centro Internacional de Mejoramiento de Maíz y Trigo).1988. From Agronomic Data to Farmer Recommendations: An Economics Training Manual. Completely revised edition. Mexico, DF.

[45] Tekalign, T., I. Hague and E.A. Aduayi, 1991. Soil, plant, water, fertilizer, animal manure and compost analysis manual. Plant Science Division (PDS), Working Document No. B13, International Livestock Center for Africa (ILCA), Addis Ababa, Ethiopia.

[46] FAO (Food and Agriculture Organization), 2000. Fertilizers and their use 4th ed. International fertilizer industry association, FAO, Rome, Italy.

[47] Mengel, K. and Kirkby, E.A. 1996. Principles of Plant Nutrition. Panimo Publishing Corporation, New Delhi, India.

[48] FAO (Food and Agriculture Organization of the United Nations), 1990. Guidelines for profile description. 3rd Edition. Rome.

[49] Landon, J.R. 1991. Booker Tropical Soil Manual: a handbook for soil survey and agricultural land evaluation in the tropics and subtropics. (eds.). John Wiley \& Sons Inc., New York.

[50] Horneck, D. A., Sullivan, D. M., Owen, J. S., and Hart, J. M. 2011. Soil Test Interpretation Guide. EC 1478 • Revised July 2011, Oregon State University Extension Service.

[51] Knezevic Desimir, Zecevic Veselinka, Stamenkovic Svetislav, Atanasijevic Srdjan, Milosevic Bozidar .2012. Variability of number of kernels per spike in Wheat Cultivars (Triticum aestivum L.). Journal of Central European Agriculture, 13(3):617-623.

[52] Akmal MS, Shah M, and Asim M. 2000. Yield performance in three commercial wheat varieties due to flag leaf area. Pakistan J. Biol. Sci., 3(12):2072-2074.

[53] Hussain M. Iftikhar, Shah Shamshad H., Hussain Sajjad and Iqbal Khalid. 2002. Growth, Yield and Quality response of three Wheat (Triticum aestivum L.) varieties to different levels of $\mathrm{N}, \mathrm{P}$ and $\mathrm{K}$. International Journal of Agriculture and Biology, 4(3):362-364.

[54] Jan, M.T. and S. Khan, 2000. Response of wheat yield components to type of N-fertilizer, their levels and application time. Pak. J. Biol. Sci., 3:1227-1230.

[55] Rehman S, Khalil SK, Rehman A, Saljoqi AU. 2008. Organic and inorganic fertilizers increase wheat yield components and biomass under rainfed condition. Sarhad J. Agric. 24(1):11-20.

[56] Geleto, T., Tanner, D.G., Mamo, T., Gebeyehu, G., 1995. Response of rain fed bread and durum wheat to source level and timing of nitrogen fertilizer on two Ethiopian Vertisols S. I. yield and yield components. Comm. in Soil Sci. and Plant Analysis, 26:1773-1794.

[57] Shirinzadeh A., Heidari H., Abad S. and Nourmohammadi G. 2017. Effect of planting date on growth periods, yield, and yield components of some bread wheat cultivars in Parsabad Moghan. International Journal of Farming and Allied Sciences, 6(4):109-119.

[58] Kauser, K., M. Akbar, E. Rasul an d A.N. Ahmad, 1993. Physiological responses of nitrogen, phosphorus and potassium on growth and yield of wheat. Pakistan J. Agric. Res., 14:2-3.

[59] Makowska, A., Obuchowski, W., Sulewska, H., Koziara, W., and Paschke, H. 2008. Effect Of Nitrogen Fertilization Of Durum Wheat Varieties On Some Characteristics Important For Pasta Production. Acta Sci. Pol., Technol. Aliment., 7(1):29-39.

[60] Bereket Haileselassie, Dawit Habte, Mehretab Haileselassie, Gebremedhin Gebremeskel. 2014. Effects of mineral nitrogen and phosphorus fertilizers on yield and nutrient utilization of bread wheat (Tritcum aestivum) on the sandy soils of Hawzen District, Northern Ethiopia. Agriculture, Forestry and Fisheries., 3(3):189-198.

[61] Jasemi, S. S., Akbari, G. A., Akbari, G. A., Najafian, G., \& Moradi, F. 2014. Nutrition management effects on grain yield, yield components and some physiological characteristics of bread wheat cultivars. International Journal of Agronomy and Agricultural Research (IJAAR), 5(3):1-6.

[62] Bekalu Abebe and Mamo Manchore. 2016. Effect of The Rate of N-Fertilizer Application on Growth and Yield of Wheat (Triticum aestivum L.) at Chencha, Southern Ethiopia. International Journal of Plant, Animal and Environmental Sciences, 6(3):168-175.

[63] Wakene Tigre, Walelign Worku and Wassie Haile. 2014. Effects of nitrogen and phosphorus fertilizer levels on growth and development of barley (Hordeum vulgare L.) at Bore District, Southern Oromia, Ethiopia. American Journal of Life Sciences, 2(5):260-266.

[64] Yasir Hayat, Zahid Hussain, Shad Khan Khalil1, Zafar Hayat Khan, Ikramullah, Muhammad Ali, Tariq Shah and Farooq Shah. 2015. Effects of Nitrogen and Foliar Sulphur Applications on the Growth and 
Yield of Two Wheat Varieties Grown in Northern Pakistan. ARPN Journal of Agricultural and Biological Science, 10(4):139-145.

[65] Haile Deressa , Nigussie Dechassa, and Amsalu Ayana. 2012. Nitrogen use efficiency of bread wheat: Effects of nitrogen rate and time of application. Journal of Soil Science and Plant Nutrition, 12(123):389409.

[66] Mulugeta Eshetu, Shure Sebboka, Tilahun Chibsa, Chala Chimdessa, Negash Bedasso. 2017. Optimization of Fertilizer Recommendations for Bread Wheat at Sinana District of Bale Zone, Southeastern Oromia, Ethiopia. International Journal of Science and Qualitative Analysis, 3(6):55-60.

[67] Ghafari, S. R., Dass, A., Hamayoun, H. , Mangal Q. M. and Omran H.A. 2017. Effect of row spacing on different wheat (Triticum aestivum L.) varieties in semi-arid region of Kandahar. International Journal of Appl Ied Research, 3(7):93-97.

[68] Gul, H., Saeed, B., Khan, A. Z., Haleema, B., Parveen, L., and Badshah, N. L.2012. Morphological and some yield attributes in Cultivars of Wheat response of varying planting dates and Nitrogen application. ARPN Journal of Agricultural and Biological Science, 7(2):100-109.

[69] Nasser, K.h. and El-Gizawy, B. 2009. Effect of Planting Date and Fertilizer Application on Yield of Wheat under No till System. World Journal of Agricultural Sciences, 5(6):777-783.

[70] White, E. M. and Wilson, F. E. A. 2006. Responses of grain yield, biomass and harvest index and their rates of genetic progress to nitrogen availability in ten winter wheat varieties. Irish Journal of Agricultural and Food Research, 45(1):85-101.

[71] Ibrahim OM, Bakry AB, Thalooth AT and El-Karamany MF. 2014. Influence of nitrogen fertilizer and foliar application of salicylic acid on wheat. Agricultural Sciences, 5:1316-1321.

[72] Foth, H.D. and Ellis, B.G. 1988. Soil Fertility. 7th Ed. John Wiley and Sons, Inc. New York, USA, 1988.

[73] Behera, U. K., Pradhan, S. and Sharma, A. R. 2010. Effect of biofertilizers and chemical fertilizers on productivity and quality parameters of durum wheat (Triticum turgidum) on a Vertisol of Central India. Archives of Agronomy and Soil Science, 56(1):65-72.

[74] Ricardo Campillo, Claudio Jobet, and P. U. 2010. Effects of Nitrogen on Productivity, Grain Quality, and optimal Nitrogen rates In Winter Wheat Cv . Kumpa-Inia in Andisols Of Southern Chile. Chilean Journal of Agricultural Research, 70(1):122-131.

[75] Atwell, W.A. 2001. Wheat Flour. Eagan Press Handbook Series. St. Paul, Minnesota, USA.Austin, R.B. 1999. Yield of winter wheat in the United Kingdom: recent advances and prospects. Crop Science, 39:1604-1610.

[76] Sadowska, J., Baszczak, W., Jelinski, T., Fornal, J., Borkowska, H. and Styk, B. 2001. Fertilization and technological quality of wheat grain. International Agro. physics, 15:279-285.

[77] Beuerlein, J. E., Oplinger, E. S. and Reicosky, D. 1992. Mineral content of soft winter wheat as influenced by nitrogen fertilization and management. Commun. Soil Sci. Plant Anal., 23:455-467.

[78] Tisdale, S. L.,W. L. Nelson, J. D. Beaton, and J. L. Havlin. 1995. Soil fertility and fertilizers, 5th ed. New Delhi: Prentice Hall of India.

[79] Kuktaite, R. 2004. Changes in Protein Polymer Composition during Grain Development and Dough Processing. Alnarp.

[80] Garrido-Lestache Elvira, Lo'pez-Bellido Rafael J., Lo'pez-Bellido Luis. 2004. Effect of N rate, timing and splitting and $\mathrm{N}$ type on bread-making quality in hard red spring wheat under rain fed Mediterranean conditions. Field Crops Research 85:213-236.

[81] Ferdoush J. N. and Rahman M. M. 2013. Effects of Boron Fertilization and Sowing Date on the Grain Protein Content of Wheat Varieties. J. Environ. Sci. and Natural Resources, 6(1): 41- 45.

Citation: Usman Kedir, Tamado Tana Wogeyehu Worku, "Effects of Blended (NPSB) Fertilizer Rates on Yield Components, Yield and Grain Quality of Bread Wheat (Triticum Aestivum L.) Varieties at Kulumsa, SouthEastern Ethiopia". International Journal of Research Studies in Biosciences. 2020; 8(9): 14-27. DOI:https://doi.org/10.20431/2349-0365.0809003.

Copyright: (C) 2020 Authors. This is an open-access article distributed under the terms of the Creative Commons Attribution License, which permits unrestricted use, distribution, and reproduction in any medium, provided the original author and source are credited. 